\title{
Placed in homecare: Living an everyday life restricted by dependence and monitoring
}

\author{
Stinne Glasdam* \\ Division of Nursing, Health Sciences Centre \\ Lund University \\ Email: Stinne.Glasdam@med.lu.se \\ * Corresponding author
}

\section{Jeanette Praestegaard}

Division of Physiotherapy, Health Sciences Centre

Lund University

Email: Jeanette.Praestegaard@med.lu.se

\section{Nina Henriksen}

Health, Man and Society, Institute of Public Health

University of Southern Denmark

Email: nihenriksen@health.sdu.dk

\begin{abstract}
Through a sociological case study this article analyses how, seen from a relational perspective, everyday life for elderly people receiving care in their own homes is lived with dependence on health-care professionals. The healthcare professionals' time and tasks are assigned and allocated in advance so that the elderly people are neither allowed nor able to vary their response in relation to the situation they encounter. The life of the client is also treated as though it were a solid, structured everyday life with minimal private time. Work in the home, for example, household chores and personal care, resembles a disciplining strategy. The client lives under conditions of monitoring and control comparable to conditions of imprisonment. The client is subject to the will of and social intercourse with other people in his own home; he both knows it is necessary and offers resistance to the conditions. In short, the authors argue that the homecare service acts as a disciplining practice in modern society.
\end{abstract}

Keywords: field study, case study, elderly, homecare, dependence, prison, Denmark, Foucault 


\section{Background}

Today, Western homecare is managed in accordance with a neo-liberal ideology based on New Public Management, which creates challenges for both the professionals and the clients (Dahl, 2005; Vabø, 2009; Dahl \& Rasmussen, 2012; Hamran \& Moe, 2012). In Denmark, elderly people have been able to apply for and to receive free and practical permanent homecare since 1958, a policy that seems quite unique to Denmark (Rostgaard \& PfauEffinger, 2011; Rostgaard et al., 2011). The municipal authorities assign and allocate assistance according to existing laws, local standards, and a personal estimate by the assessor. The assessor is forced to abide by the neo-liberal ideological values of efficiency, calculability, predictability, and control over people when it comes to allocating services (Dahl, 2005; Duncan \& Reutter, 2006; Rostgaard \& Thorgaard, 2007; Bjornsdottir, 2009; Ryberg \& Kamp, 2010; Glasdam, Henriksen, Kjaer \& Praestegaard, 2012; Hamran \& Moe, 2012; Rostgaard 2012). Clearly, the health-care professionals are subject to the structural framework and have limited autonomy for performing their professional duties. The standardization of homecare seems to challenge the professions' autonomy; however, health-care professionals are creative and adapt a multitude of strategies to mitigate the rigidity of the rules by focusing on the client and his situation (Dahl, 2009; Dahl \& Rasmussen, 2012; Glasdam et al., 2012; Rasmussen, 2012). Studies show that the elderly are to some extent violated and pre-institutionalized in their homes when they receive homecare because their everyday life often has to be arranged according to the professionals' schedules and frameworks. Furthermore, both illness and the homecare service disrupt the relationship between the client's sense of self and his home (Angus et al., 2005; Cook, 2007; Engström, 2012; Glasdam et al. 2012; Gullestad, 1989; Kofod, 2008; Lillestø, 1998; Lindahl, Lindén \& Lindblad, 2009).

It is evident that the everyday life of elderly people who receive homecare changes, partly because of disease or fragility, or both, and partly because of dependence on strangers in their homes (Angus et al., 2005; Dyck, Kontos, Angus \& McKeever, 2005; Lindahl et al., 2009; Oudshoorn, Ward-Griffin \& McWillia, 2007; McGarry, 2008). Professionals often become friends whilst they work in clients' homes, but friendships in a context of professional care are affected by the condition that those involved have not chosen each other voluntarily. They have been appointed to be with one another and their encounter is determined by the clients' disease or fragility and concomitant need for support (Lindahl et al., 2009; McGarry, 2008; Oudshoorn et al., 2007). The meeting between the elderly and the health-care professional can be seen as a negotiation of meanings of bodies and homes (Dyck et al., 2005). This article challenges prevalent understandings of these meetings and explores how elderly people who live in dependence on health-care professionals in their own homes are able to handle, decide, and act in their everyday life in relation to themselves, their relatives, and the health-care professionals.

\section{Method}

This is a single-case study designed as a field study in the home of a client receiving homecare. The case study consists of one elderly person who 
depends on health-care professionals in his everyday life, his cohabiting wife, and the health-care professionals around him. Based on observations and interviews, this study is an analysis of an individual unit comprised of persons, relationships, events, and decisions in a politically ruled health-care system. The single-case study is shown to be a valuable method when used to analyse how people frame and solve their challenges in life. The case study can also illuminate and explain the single unit so that we may be better able to understand a larger class of (similar) units (Armato \& Caren, 2002; Flyvbjerg, 2006; Gerring, 2004; Thomas, 2011).

\section{Theoretical framework}

This case study operates within a sociological theoretical framework in which discipline, power, and resistance are central, inspired by the concepts of Michael Foucault. Foucault shows how the individual is formed through the discipline applied by a series of institutions of modern society, such as the educational, military, factory, prison or hospital systems (Foucault, 1995). Discipline is identified neither with an institution nor with an apparatus. Rather, it is a type of power, a modality for its exercise, comprising a whole set of instruments, techniques, procedures, levels of application, and targets. Likewise, bureaucracies contribute to the process of 'dis-individuation' in that they promote the facelessness of the bureaucrat (Foucault, 1995). Whenever people meet, power is a condition for every relation. Power is understood as the ability to bring things into action; it has productive forces. It is important to grasp the context within which people speak and act, that is the position they speak from, in order to understand how they speak and act. Power will always generate some kind of resistance. The more visible an exercise of power is, the easier it is to oppose or react to it (Foucault, 1995). The theoretical framework of Foucault is often applied to research in the medical field (e.g., Daneski, Higgs \& Myfanwy, 2011; Nielsen \& Glasdam, 2011), and it is fitting to apply his thinking to homecare as well (Ceci, 2008; Funk, Stajduhar \& Purkis, 2011; Purkis, 2001).

\section{Recruitment}

This study took place in a Danish municipality of about 50000 inhabitants. The leaders of what we here call the Homecare Department pragmatically selected the client with whom the field study could take place. The inclusion criteria were as follows: age 65+; dependency on health-care professionals at home; fluent understanding and speaking of Danish; and acceptance that the healthcare professionals involved in the person's everyday life could be asked for their participation in the study. The client was also not to suffer from dementia or aphasia.

The chosen client lived with his wife during the field study; therefore, the spouse was also included. A discussion with the client about the formal professionals with which he had contact determined the selection of the health-care professionals. This study included two social and health-care assistants, one physiotherapist, and one homecare allocator with a background as an occupational therapist (Table 1). 


\section{Table 1: Short presentation of the persons in the case study}

The client, lan:

The client is 75 years old and has lived with his wife for 35 years. They live in their own house. He has two grown children (and three grandchildren) from a former marriage. $\mathrm{He}$ is an educated lithographer and worked as a manager for many years. The family is financially prosperous. His main interests have always been painting, art, and travelling abroad. They have a dog. For eight years he has been a dialysis patient, and he has managed his treatment himself until two years ago when he suffered cerebral thrombosis. Now he has difficulty walking and is using a wheelchair and (seldom) a walker. He receives assistance from health-care professionals for his personal care and dialysis four times daily and training by a private practising physiotherapist twice a week.

The client's wife, Sue:

The wife is 63 years old and has retired from a job as an accountant three years ago. She has no children and has been married twice. Her main interests have always been socializing with friends and family, decorating her home, and travelling abroad. She is physically healthy but has suffered with depression after her husband's illness and all the changes it brought about in the couple's everyday life.

The daytime social and health-care assistant:

The assistant is 52 years old, has three grown children, and is twice married; she has been married to her present husband, a former refugee, for 23 years. They live in a large house. They often travel to visit her husband's family in his homeland. She has been working as an uneducated post-office worker for 13 years. After two years of unemployment she began training as a social and health assistant and has been working as such for ten years now. Her husband is currently an unemployed crane operator; one of the children is studying construction, another nursing care, and the third law.

The evening social and health-care assistant:

The assistant is 53 years old and has a daughter from a former marriage who is studying to become a teacher. She has been married to her husband for 13 years; he is a cook. She studied briefly at a business school but, for many years, she has worked as an unskilled helper at a residential home. Over the last few years she has trained as a social and health-care assistant, and has worked in this position for one year.

\section{The allocator:}

The allocator is 59 years old and has three grown children (carpenter, nurse, and engineer) and a grandchild. She has married and divorced twice. She finished training as an occupational therapist in 1975 and has worked as a therapist and later a manager. Since 2003 , she has worked as allocator, whose responsibility is to distribute home-care services and has the economic responsibility and authority in the municipality.

\section{The physiotherapist:}

The physiotherapist is 34 years old and married. He qualified as a physiotherapist in 2000 and has since then worked at a hospital and in private clinics. Now he is working as a private practitioner at a large training centre. 


\section{Procedures of field study}

A three-week field study was carried out by a research assistant in the autumn of 2010 in the home of the elderly person. Appointments on days suitable for observations were made and, when needed, changed according to the family's preferences. The observations were conducted over eight days between 8 am to $10 \mathrm{pm}$. The research assistant took field notes on a laptop, constructed by a scheme containing the categories: time, place, action - what happens, actors, conversation - both verbal and non-verbal, and the researcher's immediate reflections.

The research assistant carried out the interviews with the client, spouse, and health-care professionals. The interviews took place during the field study, both when situations offered the occasion spontaneously and in more formal settings. For the spontaneous interviews the research assistant either made notes on a laptop or recorded them, depending on the situation. The formal interviews lasted about one to two hours and were conducted with a semistructured interview guide containing three categories: personal background, description of a typical day, and description of the relationships between the client, the relatives, and the professional(s). The interviews took place according to the participant's preference. The interviews were recorded and transcribed in full length.

\section{Ethical considerations}

The study followed the Helsinki Declaration (The World Medical Association, 2008). Approval by The National Committee on Health Research Ethics (2012) is not legally required for this kind of study. The study has been reported to the Danish Data Protection Agency (J. no. 2010-41-5125).

First, the leader from the Homecare Department orally informed the client and his family about the study, and then she informed the health-care professionals in the home. After they had all expressed interest in participating, the researcher informed all of them, both orally and in writing, about the study. Informed consents were obtained. All data have been anonymized and kept inaccessible to everyone but the research team. In the quotations, we have removed names, person-specific job names, and toponyms to maximize anonymity in the illustrations of the empirical material.

\section{Method of analysis}

First, we carried out a naive reading of the transcribed field notes to grasp the general meaning of the texts. Then, in order to grasp the different perspectives and speech positions of the participants, we read the texts through the research questions: who is speaking, and who is meeting whom, where, and how, with a particular focus on contexts and the relations. On the basis of this reading, we constructed analytical categories, as shown in the results section, across the empirical material, guided by the theoretical framework and the theoretical concepts of power, discipline, and resistance (Foucault, 1995). Finally, we analysed the texts within those categories, still guided by the theoretical concepts in relation to receiving and providing homecare seen from the different perspectives and positions of the participants. 


\section{Results}

We present the results of the analysis below as seen through the lens of the sociological understanding and the Foucauldian framework and therefore they incorporate and set into play the different positions of the actors. The actors met in different places in different ways and with different agendas. In general, the meetings with the assistants appear to be an important and temporally crucial part of the everyday life of the client and his wife: they were at the house of the client every day from about 8-10 am, 1-2 pm, 5-6 pm, and 8-9 $\mathrm{pm}$, helping the client with personal hygiene and handling his medical treatment. Likewise, the two weekly sessions from 11:30-12:00 am with the physiotherapist and half an hour in transport time seem to constitute a solidly integrated practice in the everyday life of the household. The homecare allocator had limited contact with the client because the homecare service was already activated.

\section{A structured everyday life with minimal private time - for everyone in the household}

It became clear that the client's - and his wife - everyday life is maintained and renewed, restored, and recreated to fit the new structural frame and becomes organized around the schedule of the homecare service. When the professionals arrive the client has to be present and ready to receive the service to which he is assigned. The client and his family have a feeling of being under pressure, and they experience limited possibilities for living compared with their previous daily life. They are dependent upon and invaded by others in their private home, and as a result of this and the disease itself, they have lost their former lifestyle. It can be seen as a loss of one's self through structural discipline and a tacit adaptation of the framework for the premises and schedule of the homecare system:

Ian explains that he cannot do the things he used to do; he needs help to get dressed, to cut the food; to go to the toilet; to do everything. Stairs have become a forbidden area, and he can no longer visit friends or family. It makes him bitter and irritable, and it is hard for his wife. They can't do what they used to: for example travel, go out. (Field notes)

The wife, moreover, is left feeling isolated in her own home:

Normally, they would visit friends or receive visitors. Now, there are many persons they can't visit any longer because of stairs; or some friends live too far away. Today she says she lives within the four walls of the house; all activity depends on time; she expresses it as 'hanging in a bell': she must do everything before or after the visit of the homecare service. (Field notes)

The client is allocated permanent staff, and he and his spouse try to incorporate the professionals as friends in their home during their working time:

Sue says that they are privileged compared with others. Because of lan's need for dialysis they have been allocated mainly permanent staff. It means that they become friends and the professionals know where 
things are placed. Sue and lan talk and have tea with the professionals in the evenings. (Field notes)

The family is aware that they need help from the professionals, that the professionals have to stay in their house for a shorter or longer time several times every day, and that they have to accept the rules of the game to receive assistance. This mode of discipline would, however, be easier for the client and his spouse to bear if they were also able to define their relationship with and socialize on an equal basis with the professionals, that is, as friends. But all in all, the client likens the experience of being dependent and disciplined into a medical client to being in Hell:

lan says that being dependent on others can be described in few words: "It is Hell! [...] I don't have the possibility of visiting my youngest son; he lives in an old flat in Xcity [...] I can't get up there at all. I would have to call (a service company) so they could carry me up [...] (and) there are only four hours between my dialyses. (Field notes)

The professionals know it is difficult for the family to be dependent on them, but they just do their jobs:

Imagine being dependent on other people in that way. In the beginning he did the dialysis himself. But suddenly, to be dependent on somebody being there four times a day for $1 \frac{1}{2}$ to two hours; I think it must feel like being in Hell. (Evening assistant)

The professionals cannot give the client his independence back owing to the fact that the client needs their help in his everyday life. The professionals personify and represent his dependence and remind him of it by their presence. Throughout the observational period the client often closed his eyes in the forced but necessary togetherness, which could be regarded as a silent resistance against his life conditions and the health-care system to which he has to be subject, as a silent whisper, 'do what you have to do; I am not present'.

\section{Self-care and self-help as a disciplining strategy}

Regardless of how dependent the client is on professionals, there seems to be an underlying idea that he can always do a little himself - and perhaps more in order that the utopian project of 'being independent of health-care professionals' could ultimately succeed; this is underpinned by the notion of activation of the elderly:

They [the client and his spouse] must not do what they can do themselves. It's important to keep them going. It's important with help to self-help [...]. It's not because I don't want to do it, but it is for your own sake that you have to do it yourself. (Evening assistant)

This could be seen as a strategy of normalization. The client is regarded as abnormal but with an immanent opportunity to become partly 'normal' again, $n$ spite of the dependence on professionals. The client seems to be met by an upbringing and educational project of the professionals in their aim of achieving self-care. The professional task 'to care for' seems to convert into a 
pedagogic project where the development of the client's self-care competences is in focus:

I don't want to be a maid for him. There are advantages to doing something yourself instead. He sleeps all day long. (Evening assistant)

And it is a disciplining project aimed at both the client and his spouse:

Earlier, lan was doing all the practical chores. And suddenly she is the one who has to do it all. I think it's too much for her. She cannot pull herself together [...]. I get annoyed by lazy people. [...] I want them to listen to me. They ask for advice but at the same time they are unable to act. (Evening assistant)

It seems as if the professionals regard psychological and physiological reactions to changes in everyday lives as 'a matter of pulling yourself together'. The client and his wife do and say what they have to do and say when the professionals are in their home. They know the rules of the professionals for correct action and behaviour. But when they are on their own, they do exactly what they are used to do: in short, lan sleeps, eats, and watches television; Sue sleeps, does some housework, watches television, and assists and serves lan. In the physical absence of the professionals, there seems to be space for elements of the usual everyday life and at the same time their behaviour is functioning as a silent resistance against the professionals' self-care and normalization strategies.

\section{Incarceration and monitoring as disciplining strategies}

The physical space of the client is very limited. At daytime, he more or less lives his life indoors in his wheelchair and at night-time he lays in bed for ten hours. It is a rare event for him to get outside the home, and that usually only happens when he visits the physiotherapy clinic twice a week. Staying outdoors seems to be beyond the daily routines of domestic life and of the professional services. It is something you must ask and obtain permission for:

lan says he wants to go out for a stroll after dialysis. But Sue turns down his request. He sleeps again. Later Sue asks if he is hungry. lan drives to the table where Sue has placed his lunch. He eats in silence, sitting next to Sue. When Ian is finished eating, Sue pushes him out on the terrace where the sun shines. (Field notes).

lan would like a ride on his scooter, but Sue slows him down because she wants to control him. But he's still an adult and he is still okay in the brain. So I say, of course, as long as he has his cell phone, he can just call if anything happens. (Evening assistant)

A person who stays at home is quite easy to monitor. He is never left on his own. Even during the interview with lan, which took place outdoors on the terrace, he was monitored. His wife came out a couple of times with blankets and the window nearby was opened so that the interview conversation could potentially be overheard. 
He was really unhappy. And he also said: 'In the past I was a director and was respected, and now I'm just here and I'm nothing. Sue never listens to me and she uses her power on me.' (Evening assistant)

Obviously, the wife's monitoring of her husband is based on good intentions. She wants the best for him and at the same time it is a big sacrifice for her, which is difficult to manage. There seems to be a delicate balance between care and violation. She cannot relinquish control over him; and in a way he has no choice because he is dependent on her in his everyday life. The only sanctuary for the client is the toilet, where the door can be locked; he can silently resist by being absent and out of reach. Being a health-care client and at the same time a spouse in one's own home seems to be a position of ongoing monitoring and observation, where the wife also consolidates the professionals' institutionalization of the home through her extended exercise of power and discipline.

\section{Regulations of behaviour as a disciplining strategy}

The professionals visit the client, and in principle the client has no impact on who is allocated and therefore who enters his home. The allocator in the local authority allocates the staff, without involving the client. The professionals have a working plan with a schedule and pre-defined tasks:

The citizen asks for house cleaning and talks about the situation. I ask for certain information in order to estimate whether the citizen is entitled to the service. [...] We have to comply with a level of service, standards of quality and legislation. (Allocator)

Both the client and the professionals have the opportunity to complain about each other to the leader of the homecare service if the interaction between them does not work out. From the perspective of the professionals a complaint carries the connotation that they may lose a task with one client and will instead be assigned tasks with another client. From the perspective of the client, a complaint implies a risk of interrupted continuity with professionals he or she knows well, which may not be wanted. In this case the client may seem to be overruled: observed, controlled, and administrated by the extended arm of the welfare systems, namely, the health-care professionals, in order to be 'normal' and to behave 'normally' in their understanding of these terms. There is a potential managerial construction of good relationships between professionals and clients, but there is also a threat that misbehaviour on the part of the client may result in punishment. There is a latent threat that the professionals to whom he had grown accustomed may disappear:

(I) told (them) that I take a break now and also why. [...] I have to take care of myself. [...] The way you have behaved towards me means that I need a break. [She does not visit the client for a week afterwards]. (Daytime assistant).

In this way, the health-care system gives more weight to the interests of the professionals than the interests of the client. Immediately this seems to lead to self-disciplining by the client. The client has to behave in an acceptable way and if not, he will be corrected or punished. He knows and resigns, a matter he returned to several times during the period of the field study. Being abnormal 
means being subject to strategies of discipline and normalization from the health-care professionals.

\section{Threat of suicide as an ultimate treat - an ultimate resistance}

The client is aware of his dependence on other people and that he is subject both to them and to their perception of his situation as abnormal. The aspiration of being re-normalized is significant. He hopes that he will be able to walk again. But behind this there is a realism and cynicism about the impossibility of this hope. In this way, the hope of being able to walk again reflects the hope of becoming normal again and the ability to escape from the situation of dependence. The ultimate reaction to the strategies of disciplining, monitoring and normalization is the threat of suicide, threat of one's finality:

If it turns out that I can't walk again, I'll commit suicide. I don't want to live this way of life. It is undignified. (Client)

The resistance produces the power relations and also their opposite: the more the client is observed and subject to the professionals and the family, the more he threatens suicide and the more the professionals and the family must observe him and vice versa. It seems to be a self-perpetuating, vicious circle.

\section{Discussion}

We have chosen a Foucault-inspired theoretical framework as the perspective for the study, knowing that many other perspectives could have been chosen. The analysis consists of detecting relationships and patterns and their various ways of being understood; it is neither an attempt to present statistical evidence that can be applied to different circumstances nor an attempt to judge if it is good or bad.

All in all, the results point to likening of a home with a prison: the structuring of time for the client; the exit permit; the discipline through self-care (work); the monitoring; and sharing of one's life with people not of one's choosing. Foucault (1995) has showed that discipline is a technology of power, used in prisons, schools, hospitals, and so on. This study indicates that the homecare service has become a disciplinary institution in modern society, one that shapes tractable clients. Other studies also show how dependence on others for assistance in everyday life makes the clients feel imprisoned within their own body and within their own home (Goffmann, 1961; Lillestø, 1998; Moore, 2000; Price, 2002; Casey, Murphy, Cooney \& O'Shea, 2008). There is a time to sleep, a time to wake up, a time to dress, a time to eat. Every day has the same rhythm and schedule. But in contrast to incarcerated prisoners, the elderly living in their own home who are dependent on health-care professionals in their everyday life have no rights in relation to going outdoors. Prisoners in Denmark have the right to go outdoors for a minimum of one hour every day; this complies with the United Nations' standard minimum rules for the treatment of prisoners (Bekendtgørelse af lov om fuldbyrdelse af straf m.v, [Consolidation Act on The Criminal Code] 2010, §43,3; United Nations, 1977). Angus et al. (2005) describe the client's dependence on family and health-care professionals in his everyday life as being 'a "prisoner" on an island'. The elderly who are dependent on health-care professionals at home are subject to the laws of health and social services (Bekendtgørelse af sundhedsloven 
[Consolidation Act on Health Care], 2010; Bekendtgørelse af lov om social service [Consolidation Act on Social Services], 2010). These laws include the right to get treatment, to be fed, have a bath, to get dressed, and to have the house cleaned, but none of them include the right for elderly people to spend some time outdoors if they are not able to do this themselves, even though the unions of health-care professionals have advocated for this right as a human right (Danish Nurses' Organization \& The Association of Public Employees, 2002). Accordingly, elderly people have to negotiate their needs for fresh air and for staying outdoors with the health-care professionals, and the healthcare professionals have to be obliging and creative in making informal space for this need in their scheduling, which seems difficult in a neo-liberal-ruled practice (Ceci, 2008; Glasdam et al., 2012; Oudshoorn et al., 2007).

Furthermore, in this case study, the client is subject to the family and the family's willingness or lack of willingness or ability to help the client outdoors. Accordingly, this form of discipline works through self-discipline, and the client more or less becomes resigned to it. On the other hand, both the family and the health-care professionals seem to be both powerful in relation to the client and powerless in relation to the conditions of their relationships with the client. The wife is in a situation where her condition of living has totally changed, her husband is changed by his worsening disease, and the professionals' time and tasks are assigned and allocated beforehand. The treatment and its management by the health-care professionals isolate the client in his home. $\mathrm{He}$ is trapped by his own disease and treatment, without even a little flexibility and with few possibilities for an exit permit.

In modern society, work has become the statutory goal of life itself, on top of being an economically determined vocation, as Weber (1972) has shown many years ago. Behind it all lurks the idea that laziness is the root of all evil Otium est pulvinar diaboli (i.e., idle hands are the devil's workshop) - or more precisely: the way the idleness is handled. Resting in order to recover from disease has disappeared from the modern medical understanding in a time where rehabilitation has replaced recreation. People must be active and work in order to get well. Work is understood both as self-therapy in relation to one's own mental health and as physical work at the labour market (Glasdam, 2011). The self-care movement seems to be an offshoot of this thinking, in the form of a pedagogical upbringing project: you can teach people to behave in the right way. It is quite similar to that of a prisoner who has the right and the duty to participate in work, education or other approved activities and must attend to practical tasks concerning personal matters, including cooking and cleaning (Bekendtgørelse af lov om fuldbyrdelse af straf m.v.[Consolidation Act on The Criminal Code], 2010). Indeed, Dahl (2005) has dealt with the reconstruction of the needs of the elderly, and shows how the emergent ideal of the active elderly by engineering development is constructed as a relatively new discourse in the homecare system. The client in homecare service has to work regardless of his evident health limitations. The disciplining of the client is increasingly functioning as a technique for making individuals useful, as Foucault (1995) has shown. A consequence is the demotion and violation of the individual in the name of discipline and self-discipline, as Lillestø (1998) also describes it, where the client loses influence over his own life. In addition, more often than not, the health-care professionals and family members' conflicting demands and expectations of him place strain on him. The client is fixed in a place, his own home, where he is spun into a web of formal and informal execution of power. The ultimate resistance from the client is his 
threat of suicide. Suicide means that all discipline strategies have failed. In many ways, the wife of the client lives under the same conditions as the client, but she still has the possibility physically to leave the home whenever she wants. She can be substituted in the life of the client. He is captured in his own body from which he cannot escape; he is chained to his own fate. The client is not able to take care of himself; if he wants to live at home he is dependent on health-care professionals in his home.

The sole realistic alternative is living in a nursing home, but several studies show that there are nearly the same conditions for living in a nursing home as at home subject to health-care professionals (Harnatt 2010; Hauge, 2004; Hauge \& Heggen 2008; Kofod, 2008; Thomasen, 2009). In comparison, prisoners cohabitate with many strangers, fellow inmates, and prison guards, but prisoners have the possibility of being alone once they have completed their duties. They can withdraw to their cells or, in specific situations, ask for voluntary isolation (Elmquist, 2009). In the present case study, the elderly person did not have the opportunity to be alone, except in the toilet and when sleeping; people - family and health-care professionals - surrounded him from when he opened his eyes in the morning until bedtime. Lillestø (1998) has shown that the toilet and the bedroom are the most private and intimate rooms in a home; this invisible border for privacy and intimacy seems to be accepted for a health-care-dependent man, even though professionals unconsciously violate a client's home through their institutionalization (Angus et al., 2005; Cook, 2007; Engström, 2012; Glasdam et al., 2012; Gullestad, 1989; Kofod, 2008; Lindahl et al., 2009). This violation of the private sphere could also be seen as a breach of the intimacy of the married couple. In other words, it is not only the private home that is invaded by the homecare system; it is also the relationship of the couple. Bachelard (1994) shows how the self is mirrored in the home, its architecture, and decor. Once the sense of home is degraded, the self is degraded. The importance of the homecare system's transformation of a client's home radically affects the client's self-perception and opportunities for self-realization and relationship; the system produces vulnerable homes and vulnerable bodies (Dyck et al., 2005).

Finally, the method of this case study has to be discussed. The construction of the single case is based on the client's perspective of his relations with his family and the formal health-care professionals, and therefore the general practitioner is not included in the case study. Clearly, this is a weakness in the study. The analyses indicate that the logic of medicine socializes and rules the homecare services as an underlining structure. Therefore the analyses probably could have been improved by including this position.

It is a well-known and well-tested anthropological method to move into the environment and context of the persons being studied, in this context a private home (Angus et al., 2005; Kofod, 2008; Terp \& Glasdam, 2009; Thomasen, 2009). With such a method, ethical dilemmas appear regarding how researchers can intrude into a private sphere, how the client and his family can accept the intrusion, and how the participants might handle the situations that arise, either individually or collectively. The researcher in this case was very aware of the participants' well-being and needs, and adjusted her observations in response to the actual circumstances. Both the interviews and the observations were carried out with an awareness of the language she used, her presence, and her genuine interest. 


\section{Conclusion}

The results show how the health-care professionals' working day and the everyday life of the client (and family) in dependence are solidly structured and disciplined by a neo-liberal logic of time allocation and scheduling that rules the homecare system.

All in all, everyday life in dependence on health-care professionals (and family) in one's home resembles a life in imprisonment, but with fewer human rights than prisoners. The clients assigned to homecare services have neither the human right to get out every day nor the right to visit friends and relatives. Furthermore, the clients have no influence on the staff composition in their home and are thus forced to incorporate strangers into their life. Homecare services could be viewed as a disciplining institution of society to normalize and discipline the clients through work, routines, and rules. Self-care can be seen as an underlying strategy to become re-normalized, in which the ultimate and illusory goal of the professionals is an independent client. One result is that the toilet and the bed are the only private places in the home. In all other places, the client seems to be incarcerated and monitored by the health-care professionals or the family. The family of the client magnifies those disciplinary strategies. Punishment is a part of the disciplining system: the utmost consequence is the withdrawal of the health-care professionals. On the other hand, the health-care professionals' time and tasks are assigned and allocated beforehand, and so they are neither allowed nor able to respond to the situation in the home. The client rebels and resists in small ways through signalizing his 'non-existence' in the situation and not doing what he is asked to do, but the ultimate resistance to the power is the threat of suicide. It becomes a vicious circle where everybody reinforces and amplifies the power relations and the power strategies. The client and the family are not only stuck at home, they are stuck in a home that is 'broken'.

These results are only based on one case. Although the case study with its theoretical analyses has implications on a general level, the results may be regarded as limited and must be qualified in a larger study with more client cases.

\section{Acknowledgements}

The authors thank the municipality where the case study took place and all participants. We also thank Lone Kjaer for her assistance with the project. We are also grateful to our colleagues Kristin Bjørnsdottir (Iceland), Frode Fadnes Jacobsen (Norway), Inge Storgaard Bonfils, Claus Fenger, and Marianne Munksgaard (Denmark) for their critical comments on the draft of this article. We also thank Penny Bayer (UK) for proof reading the manuscript. 


\section{References}

Angus, J., Kontos, P., Dyck, I., McKeever, P, \& Poland, B. (2005). The personal significance of home: habitus and the experience of receiving long-term home care. Sociology of Health and IIIness, 27(2), 161-187.

Armato, M., \& Caren, N. (2002). Mobilizing the Single-Case Study: Doug McAdam's Political Process and the Development of Black Insurgency, 1930-1970. Qualitative Sociology, 25(1), 93-103.

Bachelard, G. (1994). The Poetics of Space. Boston: Beacon Press.

Bekendtgørelse af lov om fuldbyrdelse af straf m.v. [Consolidation Act on The Criminal Code] no. 1162 af 05/10/2010

Bekendtgørelse af lov om social service [Consolidation Act on Social Services] no. 1096 af 21/09/2010

Bekendtgørelse af sundhedsloven [Consolidation Act on Health Care] no. 913 af $13 / 07 / 2010$

Bjornsdottir, K. (2009). The ethics and politics of home care: a discussion paper. International Journal of Nursing Studies, 46(5), 732-739

Casey, D., Murphy, K., Cooney, A., \& O’Shea, E. (2008). Patient perceptions having suffered a stroke in Galway. British Journal of Community Nursing, 13(8), 384390.

Ceci, C. (2008). Increasingly distant from life: problem setting in the organization of home care. Nursing Philosophy, 9(1), 19-31

Cook, G. A. (2007). Life as a care home resident in later years: 'living with care' or 'existing in care'. Ph.D.-Dissertation. Newcastle: Northumbria University.

Dahl, H. M. (2005). A changing ideal of care in Denmark: A different form of retrenchment. In H.M. Dahl \& T.R. Eriksen (Eds.),Dilemmas of care in the Nordic welfare state (pp. 47-61). Aldershot, Hants: Ashgate Publishing Limited.

Dahl, H. M. (2009). NPM, disciplining care and struggles about recognition. Critical Social Policy, 29(4), 634-654.

Dahl, H. M. \& Rasmussen, B. (2012). Paradoxes in elderly care: The Nordic model. In A. Kamp \& H. Hvid (Eds.), Elderly care in transition - management meaning and identity at work (pp. 29-49). Copenhagen: Copenhagen Business School Press

Danish Nurses' Organization, The Association of Public Employees (2002). AEldres rettigheder http://www2.dsr.dk/msite/text.asp?id=103\&TextID=469 (accessed on 10.07.2012)

Daneski, K., Higgs, P., \& Myfanwy, M. (2011). How far can Foucault take us? An analysis of the changing discourses and limitations of the medical treatment of apoplexy and stroke. Health: An Interdisciplinary Journal for the Social Study of Health, Illness \& Medicine 15(4), 369-84

Duncan, S. \& Reutter, L. (2006). A critical policy analysis of an emerging agenda for home care in one Canadian province. Health and Social Care in the Community 14(3), 242-253. 
Dyck, I., Kontos, P., Angus, J., \& McKeever, P. (2005). The home as a site for longterm care: meanings and management of bodies and spaces. Health \& Place 11(2), 173-185.

Elmquist, B. (2009). Frivillig isolation kan erstattes af fodlænker. [Voluntary isolation can be replaced with ankle monitors] Copenhagen: Retspolitisk Forening.

Engström, L. (2012). Kliniken flyttar hem. Sjuksköterskans institutionella praktik inom specialiserad palliativ hemsjukvård. [The clinic moves home: the nurse's institutional practice in specialized palliative care.] Ph.D.-Dissertation. Uppsala Studies in Education 128. Uppsala: Uppsala University

Flyvbjerg, B. (2006). Five misunderstandings about case-study research. Qualitative Inquiry ,12(2), 219-245

Foucault, M. (1995). Discipline and Punish: The Birth of the Prison. London: Vintage.

Funk, L. M., Stajduhar, K. I., \& Purkis, M. E. (2011). An exploration of empowerment discourse within home-care nurses' accounts of practice. Nursing Inquiry, 18(1), 66-76

Gerring, J. (2004). What is a case study and what is it good for? American Political Science Review, 98(2), 341-354.

Glasdam, S. (2011). Sandwiched between disease and job - on cancer patients' meetings with the requirements of job center in relation to job activity. Klinisk Sygepleje, 25(4), 25-35.

Glasdam, S., Henriksen, N., Kjaer, L., \& Praestegaard, J. (2012). Client involvement in Home Care Practice -a relational sociological perspective. Nursing Inquiry DOI: 10.1111/nin.12016

Goffman, E. (1961). Asylums: Essays on the Social Situation of Mental Patients and Other Inmates. New York: Doubleday.

Gullestad, M. (1989). Kultur og hverdagsliv. [Culture and everyday life] Oslo: Universitetsforlaget.

Hamran, T. \& Moe, S. (2012). Yngre og eldre brukere i hjemmetjenesten - ulike behov eller forskjellsbehandling. Flerfaglig praksis i et interaksjonsteoretisk perspektiv. [Younger and older users in homecare services: different needs or different treatment. Multi-disciplinary practice in an interactional theoretical perspective.] Rapportserie nr. 3. Tromsø: Senter for omsorgsforskning.

Harnatt, T. (2010). The trivial matter: Everyday power in Swedish elder care. Ph.d.Disseration. Jönköbing: Jönköbing University.

Hauge, S., 2004. Jo mere vi er sammen, jo gladere vi blir? Ein feltmetodisk studie av sjukeheimen som heim. [The more we are together, the happier we become? A field study of a nursing home as a home.] Ph.D.-Dissertation. Oslo: Oslo University.

Hauge, S., \& Heggen, K. (2008). The nursing home as a home: a field study of residents' daily life in the common living rooms. Journal of Clinical Nursing 17(4), 460-467

Kofod, J. (2008). Becoming a Nursing Home Resident. An Anthropological Analysis of Danish Elderly People in Transition. Ph.D.-Dissertation no. 49. Copenhagen: Copenhagen University. 
Lillestø, B. (1998). Når omsorgen oppleves krenkende. En studie av hvordan mennesker med fysiske funksjonshemninger opplever sitt forhold til helsetjenesten. [When care is experienced as insulting: a study of how people with physical disabilities experience their relationship to the health services.] NF-report nr. 22.Norland: Norlands Forskning Institute.

Lindahl, B., Lindén, E., \& Lindblad, B-M. (2009). A meta-synthesis describing the relationships between patients, informal caregivers and health professionals in home-care settings. Journal of Clinical Nursing, 20(3-4), 454-463

McGarry, J. (2008). Defining roles, relationships, boundaries and participation between elderly people and nurses within the home: an ethnographic study. Health and Social Care in the Community ,17(1), 83-91

Moore, J. (2000). Placing home in context. Journal of Environmental Psychology, 20(3), 207-17.

Nielsen, K. T. \& Glasdam, S. (2011). Death in nursing home - A Foucault inspired analysis of the discourses of death and caring in Danish nursing homes in this millennium. Vård I Norden, 31(1), 39-44

Oudshoorn, A., Ward-Griffin, C., \& McWillia, C. (2007). Client-nurse relationships in home-based palliative care: a critical analysis of power relations. Journal of Clinical Nursing, 16(8), 1435-1443

Price, J. M. (2002). The apotheosis of home and the maintenance of space of violence. Hypatia, 17(4), 39-70.

Purkis, M. E. (2001). Managing home nursing care: visibility, accountability and exclusion. Nursing Inquiry, 8(3), 141-150

Rasmussen, B. (2012). New Public Management: Construction a new management identity in care for the elderly. In A. Kamp \& H. Hvid (Eds.), Elderly care in transition - management meaning and identity at work (pp. 165-187). Copenhagen: Copenhagen Business School Press:

Rostgaard, T., \& Thorgaard, CH. (2007). God kvalitet i ældrepleje. Sådan vægter de ældre, plejepersonale og visitatorer. [Good quality in elderly care: what the elderly, care personnel, and visitors emphasize] Nr. 07. Copenhagen: SFI-The Danish national centre for social research.

Rostgaard, T., \& Pfau-Effinger, B. (2011). Welfare-state change, the strengthening of economic principles, and new tensions in relation to care. Nordic Journal of Social Research, (special issue) 2, 1-6

Rostgaard, T., Glendinning, C., Gori, C., Kröger, T., Österle, A., Szebehely, M., Theobald, H., Timonen, V., \& Vabø, M. (2011). LIVINDHOME: Living independently at home. Reforms in home care in 9 European countries. Copenhagen: SFI-The Danish National Centre for Social Research.

Rostgaard, T. (2012) Quality reforms in Danish home care - balancing between standardization and individualization. Health and Social Care in the Community, 20(3), 247-254

Ryberg, M. \& Kamp, A. (2010). Hjemmeplejen. Standardisering, faglighed og indflydelse. [Homecare: standardization, professionalism, and influence] Copenhagen: Copenhagen Business School \& Roskilde University.

Terp, M. Ø. \& Glasdam, S. (2010). Inner voices. Klinisk Sygepleje, 2, 26-36

The National Committee on Health Research Ethics (2012). http://www.dnvk.dk/ (accessed 05.07.12) 
The World Medical Association (2008). WMA Declaration of Helsinki - Ethical Principles for Medical Research Involving Human Subjects. Seoul

Thomas, G. (2011). A typology for the case study in social science following a review of definition, discourse and structure. Qualitative Inquiry, 17(6), 511-521

Thomasen, L. S. (2009). En god alderdom? Aktivering af svækkede ældre i levebomiljøer. [A good old age? Activation of weakened elderly in residential environments] Master thesis. Copenhagen: Copenhagen University.

United Nations (1997). Standard Minimum Rules for the Treatment of Prisoners. http://www2.ohchr.org/english/law/pdf/treatmentprisoners.pdf (assessed on 10.07.12)

Vabø, M.(2009). Home care in transition: the complex dynamic of competing drivers of change in Norway. Journal of Health Organization and Management, 23(3), 346-358

Weber, M., (1972). Den protestantiske etik og kapitalismens ånd. [The Protestant ethic and the spirit of capitalism] Copenhagen: Fremad. 